\title{
Racismo e Intolerância Religiosa: Representações do Xangô nos jornais de Maceió entre 1905 e 1940
}

Lwdmila Constant Pacheco ${ }^{1}$

Resumo: Esse trabalho busca explicitar as expressões linguísticas com que o Xangô em Maceió foi representado nos jornais de grande circulação, principalmente no Jornal de Alagoas, entre os anos de 1905 e 1940. O objetivo é destacar o discurso racista com que se referiam às religiões de matriz africana e de como esse se expressava em práticas racistas que incitaram a violência ocorrida no ano de 1912 e o seu prolongamento no tempo, com maior intensidade nos anos de 1930. Tal constatação tem o intuito não só de demarcar o racismo na linguagem escrita da mídia da época, como provocar a discussão sobre as consequências em relação à incitação da violência. Isto é, compreender a função que a linguagem exerce na formação de concepções enraizadamente racistas e eurocêntricas na população alagoana das primeiras décadas do século XX.

Palavras-chave: Racismo; intolerância religiosa; Maceió.

Keywords: Racism; religious intolerance; Maceió.

\begin{abstract}
This work seeks to clarify linguistic expressions with the Shango in Maceió was represented in major newspapers, mainly in the Journal of Alagoas, between the years 1905 and 1940. The aim is to highlight the racist discourse that refer to religions with African roots and how this was expressed in racist practices that incited the violence in 1912 and its extension in time, with greater intensity in the 1930s. This finding is intended not only to demarcate racism in the written language of the media of the time as provoke discussion about the consequences in relation to incitement of violence. That is, to understand the role that language plays in the formation of racist and Eurocentric conceptions in population in Alagoas in the early decades of the twentieth century.
\end{abstract}

\section{INTRODUÇÃO}

No fim do século XIX a abolição da escravatura negra no Brasil se tornou inadiável por pressões internacionais. Estas exigiam o fim da escravidão por ser este sistema contrário aos interesses relativos do livre comércio ansiado pela Europa. Também por interesses nacionais

1 Psicóloga formada pela UFAL, pós graduada em História Social do Poder pela UFAL, mestra em Psicologia Social e Política pela Universidade Federal de Sergipe. 
abolicionistas surgiu a necessidade de decidir qual o destino da população negra que, à época, tinha se transmutado em um “empecilho” à formação nacional, que se pensava branca e europeia. Além do que, segundo Conrad, o espírito rebelde dos escravizados refletido através de fugas, formação de quilombos, assassinatos de senhores, suicídios, etc, principalmente nas últimas décadas da escravatura, foi mais um fator de fragilização do escravismo (1978, p. 18).

A transição do trabalho escravo para o assalariado foi pensada, a princípio, através da disciplinarização do ex-escravizado e seus descendentes, além de pobres em geral, no sentido de prepará-los para o trabalho livre. Porém, tal perspectiva foi substituída sob a influência das teorias científicas raciais produzidas na Europa e nos Estados Unidos, que defendiam hierarquias raciais que posicionavam o negro e o indígena numa condição inferior. O racismo se legitima, já que teorias defendem que negros e indígenas impedem o progresso de uma dada sociedade, e a miscigenação gera a degeneração das “raças mais evoluídas” (AZEVEDO, 2008). Tais teorias ganham espaço entre intelectuais e autoridades políticas legitimando o racismo.

Através da perspectiva do racismo científico inicia-se o estímulo a imigração como estratégia de substituição física dos escravizados e pobres em geral. Segundo Azevedo (2008), o projeto imigrantista com intuito de trazer mão-de-obra livre em substituição à escrava começou a ser praticado em São Paulo em 1840 na fazenda Ibicaba, do senador Nicolau Vergueiro. Nessa época, o tráfico de africanos diminui por conta de sua ilegalidade. A transição da escravidão para o trabalho livre ganhou assim, a perspectiva da substituição da mão-de-obra dos escravizados.

Em Alagoas, o bacharel em Direito e deputado pelo Estado em 1861, Aureliano Cândido Tavares Bastos, era um dos grandes divulgadores das reformas políticas e sociais. Entre essas reformas, destacava-se a questão relativa à criação de condições propícias para a vinda massiva de imigrantes, fundando a Sociedade Internacional de Imigração. Segundo Tavares Bastos, com a abolição vindoura, era preciso reparar os estragos do sistema escravista, estragos estes que eram supostamente degradantes por culpa do próprio escravizado que, em sua condição inferior, degradava o trabalho.

A população negra e mestiça, desprezada pelo trabalho formal, se estabeleceu nos bairros periféricos da capital alagoana - Maceió, sobrevivendo de trabalhos informais na sua maioria. Essa “informalidade”, (AZEVEDO, 2008), ao invés de causar invisibilidade provocava uma ameaça constante, visto que a população negra, excluída das instituições sociais dominantes, detinha certo 
grau de autonomia que escaparia a coibição das leis repressivas. A resistência seria uma força desproporcional que subverte a opressão através de bricolagens (CERTEAU, 1998). Isto é, a opressão, uma força superior à resistência, pressiona os oprimidos que, como única opção, criam formas de corromper a opressão cotidiana através de sua reinterpretação.

O que aparentava uma harmonia racial e social se revelava um apartheid simbólico em que a geografia e as formas de valorização cultural e estética tendiam a marginalizar a população de descendentes de africanos, ex-escravizados. Ao mesmo tempo em que se aumentava a tensão provocada pela repressão. Dessa forma, surgiam manifestações de intolerância por parte dos dominantes - oficiais e extra-oficiais, que de naturalizadas não eram contestadas, como a proibição da capoeira (Código Penal, Decreto número 847, de 11 de outubro de 1890) e o combate aos feiticeiros, ficando proibidos os chamados baixo espiritismo, magia e curandeirismo pelo Código Penal de 1890. Assim, a passagem do século XIX para o século XX estruturou novas formas, mais sutis, de exclusão e discriminação.

Um evento acontecido em Alagoas no início do século XX deixou marcas permanentes na cultura local, que renega ou invisibiliza sua herança africana: O “Quebra de Xangô" ocorrido no ano de 1912. Tal evento de extrema violência foi forjado ou "justificado” na consciência das elites graças a uma linguagem racista, a princípio sutil e subliminar que, posteriormente, ganhou caráter direto e escancarado, expresso em panfletos e jornais de circulação local encabeçado por um grupo político de oposição ao governador vigente. O intuito foi não só relacionar o dito governador às práticas afro-religiosas, como fomentar uma higienização racial. Pois, como descreve Félix Lima Junior (2001, p.133), Era necessário derrubar a situação dominante, “salvar” a terra de Floriano (...). Tal linguagem ganhou familiaridade à população da época que convivia com os negros, negras e suas nuances cultural-religiosas com uma espécie de asco comedido. Insuflada pelos jornais, alguns setores da população se vê despida de culpa e pudor, assumindo a condição de massa de manobra, execrando as casas de Xangô de Maceió e cidades circunvizinhas.

\section{A PRESENÇA NEGRA EM ALAGOAS NA PASSAGEM dO SÉCULO XIX PARA O} $\mathbf{X X}$

Alagoas era uma região localizada ao sul da Capitania de Pernambuco até o ano de 1817, quando se emancipou tornando-se Capitania de Alagoas. Eleita comarca no ano de 1774, Alagoas já 
mantinha focos de povoamento desde o século XVI, a exemplo de Penedo, fundada em 1575, e Porto Calvo em 1585. Segundo Lindoso (2011), de Penedo partiu a conquista dos sertões alagoanos, e de Porto Calvo, a sociedade tutelar dos donos de terras, de escravizados e de fábricas de açúcar. Nessa época, a escravidão negra servia, principalmente, para o cultivo da cana de açúcar, matériaprima que foi essencial para o desenvolvimento dos engenhos banguês. E foi graças ao processo de destruição do Quilombo dos Palmares, a partir de 1664, com a distribuição das terras quilombolas para a devida colonização, que foi se formando a antiga Capitania de Alagoas (LINDOSO, 2011, p. 45).

Apesar da constante tensão entre negros e brancos, senhores e escravos e da hierarquia da cor estabelecida no país durante a escravidão, que legitimava a opressão e as constantes contraofensivas dos oprimidos, constata-se que na Alagoas do período imediatamente após a abolição, havia uma espécie de "pseudotolerância” para com essa população que afirmava a cultura afrobrasileira. Essa tolerância era sustentada, dentre várias hipóteses, pelo medo sentido pelos hegemônicos ainda como uma herança escravista, onde a quilombagem (MOURA, 2001) gerava uma tensão constante entre os senhores de escravos e suas "peças”. Esse medo dizia respeito à ameaça dos quilombos e das rebeliões do contingente escravizado, que era numericamente superior aos brancos livres e escravagistas.

Ianni (1978) concorda que o medo sentido pelos colonos no período escravocrata instigava a violência praticada contra os escravizados, que eram sua propriedade ao mesmo tempo em que eram seus inimigos. Porém, para ele, essa justificativa precisa estar associada à condição do sistema vigente que tinha a escravidão como sistema de produção de mais-valia absoluta. O escravizado é, ao mesmo tempo, produto e força de trabalho. Com isso, é alienado duplamente: como pessoa, enquanto propriedade do senhor, e em sua força de trabalho, faculdade sobre a qual não pode ter comando.

Esse medo colonial se estende para o período pós-abolição reformulado, assim como as estratégias de exclusão da população negra. Havia um controle das manifestações culturais negras por parte das autoridades legais (RAFAEL, 2004). Por mais que se proibisse a capoeira, a religião de matriz africana, e outras manifestações, elas foram rodeadas de um misticismo ameaçador que provocava na população branca (ou que assim se considerava) um respeito forçado.

Assim, como um respeito construído através do desconhecido que gera medo, também a 
condição cultural brasileira e, mais especificamente, a alagoana de influência africana, cria uma particular familiaridade que induz a convivência, mesmo que invisível, dessas variações culturais.

Porém, mesmo adquirindo um jeito de andar e falar de herança africana, mesmo havendo a presença africana na cama, mesa, musicalidade e do misticismo no catolicismo popular (FREYRE, 2001), mesmo existindo também esse comportamento amedrontado e/ou familiarizado que fazia com que parte da população alagoana tolerasse a presença negra na melanina dos corpos, batuques de atabaques, roupas de axé e demais manifestações da resistência africana, em determinado momento histórico de Alagoas, se torna valorizado o repúdio a essa presença.

\section{POLÍTICA OLIGÁRQUICA E MISTICISMO: EUCLIDES MALTA E O XANGÔ EM} ALAGOAS, 1912

Após um longo período militarista no Brasil, Prudente de Morais assumiu o governo federal e, como relata Apratto (2009, p. 73) (...) foi desmontando a estrutura criada no governo anterior $e$ desmilitarizando o país; por isso, sofreu forte reação jacobina. O liberalismo que preconiza a descentralização do poder central promoveu autonomia aos Estados que, marginalizando as camadas populares, derrotando os últimos inconformados monarquistas e os republicanos militaristas (APRATTO, 2009, p. 74), fez das elites agrárias estaduais o centro do controle governamental nos estados do Brasil. Todos os possíveis cargos políticos/governamentais foram, nesse período, ocupados por membros de famílias tradicionais.

Com capital financeiro suficiente para ser convertido em capital social (BOURDIEU, 2007), isto é, poder político, essas famílias instauraram um comportamento de submissão e dependência entre seus membros e o eleitorado. Criou-se a tradição do coronelismo e seus currais eleitorais, caracterizando a República brasileira como oligárquica.

Em Alagoas, estabelece-se a oligarquia Maltina que durou doze anos. Euclides Malta foi um político sertanejo do município de Mata Grande, casado com a filha do renomado Barão de Traipú, governador do Estado de Alagoas entre 1891 e 1897, e que com seu prestígio ajudou a eleger o genro governador de Alagoas em 12 de junho de 1900. Seu governo foi marcado pelo controle partidário, dos órgãos municipais, pela prática clientelista, pelo nepotismo e patrimonialismo. Porém, apesar de uma postura caudilhesca, Euclides Malta se mostrou um diplomático líder de 
Estado ao estabelecer alianças com representantes de segmentos hegemônicos, criando um clima pacífico entre as classes agrárias, fornecendo ajuda a instituições e prestigiando a Igreja Romana (APRATTO, 2009).

A liderança de Euclides Malta no Estado se estendeu mesmo quando seu irmão o sucedeu entre 1903 e 1905, à medida que sua própria reeleição estava impossibilitada por questões de ordem constitucional. Para superar a impossibilidade de permanecer no governo, promoveu uma reforma institucional com intuito de se tornar independente do sogro e se reeleger. Tal reforma foi possibilitada pelo clientelismo (a chamada "política dos governadores” instituída pelo presidente Campos Salles, que governou de 1898 a 1902. Tal manobra gerou um rompimento com o sogro e críticas na sua própria base de apoio, além do fortalecimento da oposição liderada por José Fernandes Lima. Mesmo havendo uma reaproximação de genro e sogro no ano de 1906, o que garantiu a eleição de Euclides Malta para o governo do Estado novamente, o desgaste de governo tão longo somado às mudanças nacionais, como a volta do militarismo à presidência nacional, fez com que as oligarquias fossem perdendo força.

Uma campanha anti-oligárquica se iniciou no país e em Alagoas ganhou força no ano de 1911 principalmente após a oposição divulgar o nome de Clodoaldo da Fonseca para a candidatura do Estado - figura popular, parente do então presidente da República Hermes da Fonseca e pertencente ao exército. Fernandes Lima, um dos oposicionistas, aproveitou a situação de mudança no Estado e de insegurança do governo vigente para, em dezembro de 1911, insuflar a população a não mais pagar os impostos, aumentando ainda mais o clima de desorganização e conflito na sociedade alagoana. Segundo Júnior (2001), tal ação foi praticada através de boletim distribuído pela cidade de Maceió pelos membros da Liga dos Republicanos Combatentes, que dizia que os impostos municipais e estaduais eram ilegais e exorbitantes e que, se a população não os pagasse diminuiriam os valores de compra e venda de gêneros alimentícios em todo o Estado.

Sofrendo com o crescimento oposicionista que finalmente se organizava numa força política graças às manobras de alteração da constituição para favorecer a oligarquia maltina e o afastamento de Euclides Malta do seu sogro, o Barão de Traipú, o governo passou a se defender publicamente quanto aos ataques sofridos, como mostra o jornal A Tribuna no dia 12 de maio de 1905:

Já não se pode contestar que a posse absoluta da verdade que nos assiste, 
nos dá o direito de censurarmos a facilidade com o opposicionismo, baldo de razões para manter-se, architecta factos a seu bel prazer afim de armar effeito. Um prova iniludível do nosso asserto resulta do contraditório artigo do Correio de hontem, no qual os nossos adversário revelaram a sua fraqueza para corresponder na altura que eram obrigados ao repto que lhes lançamos, desafiando-os a que exhibissem as provas dos actos attentatórios dos direitos dos nossos concidadãos, commetidos pelo criterioso e honrado sr. dr. governador do estado. ${ }^{2}$

Somaram-se às críticas da imprensa aos governistas, boletins distribuídos à população e a instalação no dia 17 de dezembro de 1911 da já citada Liga dos Republicanos Combatentes em Homenagem a Miguel Omena, uma espécie de guarda revolucionária popular (APRATTO, 2009, p. 97) que tornou ainda mais tensa a disputa pela predileção nas eleições vindouras. A Liga, comandada pelo militar reformado do Exército, Manoel Luís da Paz, encabeçou várias ações atacando o governo vigente. Após poucos dias de sua fundação, reuniu-se no Mercado forçando comerciantes a fecharem suas lojas e barracas e encerrarem seu expediente às 9 horas da manhã, invadindo, posteriormente, a residência do intendente da capital, Luís Mascarenhas. Segundo Júnior (2001), para estabelecer o pânico na cidade, grupos de desordeiros capitaneados pelos combatentes da Liga, fizeram fechar às pressas o Mercado Municipal na véspera de natal do ano de 1911. Também, no intuito de fazer o intendente Dr. Luiz de Mascarenhas renunciar ao cargo, o insultaram e chegaram a (...) fazer uma diversão, à bala, em frente a residência do gestor dos negócios municipais (JÚNIOR, 2001, p. 154).

Euclides Malta, nesse momento, pediu para a polícia intervir nos comícios antigovernamentais e provocou uma "guerrilha" na capital alagoana. Pois, a quantidade de opositores entre populares se tornava cada vez maior e mais ensandecida. Pessoas ligadas ao governo se mudaram para o interior por medo da invasão de suas casas. Os membros da Liga invadiram também o Palácio dos Martírios, desarmando os guardas e expulsando o chefe do Executivo, que se refugiou em Recife; também alvejaram a casa do vice intendente.

O governo federal, a pedido de Euclides Malta, interveio na balburdia alagoana pedindo a Clodoaldo que retirasse sua candidatura em nome da pacificação do Estado. Este não o fez, ao contrário, oficializou sua candidatura pelo Partido Democrata, tendo Fernandes Lima como vice.

Promessas salvacionistas da oposição cooptaram a maioria da população e incitarem a

2 A Tribuna. Oxalá. 12 de maio de 1905, p. 2. Catálogo Odè-Ayé. 
propaganda negativa contra a oligarquia Malta, não negando esforços para demonizá-la. Cidades do interior também aderiram à campanha anti-maltina - União dos Palmares, Viçosa, Capela e Penedo - e até Delmiro Gouveia, empresário do sertão do Vale do São Francisco, simpatizou com a causa e a apoiava às escondidas.

A oposição, que já tinha atacado Euclides Malta por todos os lados não podia deixar de atacar sua suposta ligação com as Casas de religião de matriz africana, os chamados Xangôs. Euclides Malta, assumidamente católico, era associado extra-oficialmente às Casas de Xangô, em grande número pela capital nesse período. Assim, através dessa rede de relações e a inevitabilidade da deposição do governo, como um ato de desforra final, as Casas de Xangô foram atacadas pelos populares e praças da guarnição, que quebravam tudo o que encontravam e recolheram à cadeia os mais afamados pais de santo.

Tal fato, herdeiro de um processo de sublevação contra o governo vigente, teve seu ápice em fevereiro de 1912, e serviu como alavanca política para a destituição definitiva de Euclides Malta do governo. Parte da sociedade alagoana que já se encontrava insatisfeita com a situação econômica do Estado e após a campanha de desmoralização do governo, viu sua moral cristã ser atacada com a presença da religião africana não só nas ruas da cidade de Maceió, mas como mantenedora de Euclides Malta no poder.

Euclides Malta, que saiu de Maceió em busca de apoio, ainda voltou do Rio de Janeiro escoltado, tentando reassumir seu cargo. Mas além de todas as formas de rechaço com que fora recebido (vaias, comércio fechado, sinos de finados tocando nas igrejas, ovos podres e lamas de sururu) teve a morte de manifestantes a mando do tenente Brayner que veio defender o governador do Estado. O próprio Brayner foi ferido fatalmente no confronto, além do jovem advogado Bráulio Cavalcante. Assim, sem perspectiva de se manter no poder, Euclides Malta parte para Pernambuco e nunca mais volta a Alagoas, findando sua longa oligarquia.

Os objetos ritualísticos do Xangô que não foram quebrados e queimados durante a devassa de 2 de fevereiro de 1912 serviram a uma exposição de zombaria através de passeatas pela capital e ficaram expostos com a mesma intenção no Jornal de Alagoas. Tais objetos foram doados posteriormente pela Liga dos Republicanos Combatentes ao Museu do Comércio, gerido naquele ano de 1912 pela Sociedade Perseverança de Auxílio. Em 1940, a Sociedade Perseverança de Auxílio, doou tais objetos ao Instituto Histórico e Geográfico de Alagoas (IHGAL) onde 
permanecem atualmente (RAFAEL, 2004).

O episódio de 1912 marcou uma espécie de “estado de sítio” no Estado em relação ao Xangô. Algumas Casas de Xangô tradicionais se mudaram de Alagoas, outras se desfizeram ou silenciaram-se, criando estratégias para sobreviver no sentido de passarem despercebidas à perseguição, visto que o evento de 1912 não foi um evento isolado: a perseguição se manteve durante um longo tempo com prisões, torturas, delações e interrogatórios, instituindo-se o que denomina Douglas Apratto, como um “terrorismo político-religioso” contra os adeptos dos cultos de matriz africana, impedindo a sua reorganização.

Por ainda haver perseguição, e por medo dela se repetir, criou-se uma nova modalidade de executar os cultos de matriz africana em Alagoas. Segundo Gonçalves Fernandes (1941), sem sons, batuques, escondidos nos quintais das casas: estabelecer-se-ia o "xangô rezado baixo 3". Porém, há controvérsias sobre o silenciamento, pelo menos no sentido total, dos Xangôs em Alagoas, visto que fontes de jornais informam que anos após o Quebra de Xangô, algumas Casas eram novamente invadidas pela polícia por causa do barulho que provocavam e incomodavam a vizinhança.

\section{A IMPRENSA E SUA FUNÇÃO LEGITIMADORA DA PERSEGUIÇÃO DOS} XANGÔS

Foi durante a elaboração das reformas constitucionais brasileiras que foi instalada em Maceió a primeira tipografia, na década de 1920. Segundo Craveiro Costa (1931), o Íris Alagoense foi o primeiro jornal a ser publicado no Estado, circulando as quartas e aos sábados, e se definia como um jornal político, literário e mercantil. Porém, como Craveiros Costa relata, o jornal com suas matérias anônimas, refletia sua opinião sobre os tumultos da época no Estado, além de expor intrigas das disputas que ameaçavam reputações, provocando conflitos pessoais entre figuras públicas. No final do século XVIII e começo do século XIX surgiram cerca de 500 jornais e periódicos em Alagoas (COSTA, 1902 apud MACIEL, 2004). O autor define a imprensa como um apêndice da política, visto que seu surgimento está diretamente ligado a interesses de grupos oligárquicos. Assim, as notícias que se registram nos jornais tendem a orientar opiniões em favor

3 Título registrado por Gonçalves Fernandes quando da visita à Maceió em 1930, descrito por ele como: ritual discreto, sem atabaques, sacrifícios de animais ou grandes festividades públicas com um toque de sincretismo veementemente marcado (FERNANDES, 1941). 
deste ou daquele grupo. Craveiro Costa (1931) assim, nos mostra que desde sua fundação a imprensa em Alagoas sempre teve seu partidarismo político, e isso não mudou no século XX.

No início do século XX, quando Euclides Malta ascendeu ao poder, os oposicionistas se dispersaram, resistindo apenas alguns radicais que não faziam propriamente a política partidária, mas manifestavam-se no Jornal de Debates (COSTA, 1931, p. 125). Dentre os oposicionistas que escreviam no Jornal de Debates encontram-se o próprio Craveiro Costa e o Barão de Traipú, que aderiu a oposição no momento em que Euclides Malta colocou seu irmão, Joaquim Paulo Viera Malta, em seu lugar como governador do Estado. Também servindo a oposição dissidente, surge o jornal Correio de Alagoas em 1904, dirigido por Angelo Neto e Craveiro Costa.

A favor da situação política dominante, tem-se o jornal A Tribuna, sob a redação de Carlos Valente, Seipião Jucá, Bernadino Ribeiro e Alfredo de Maia. Além desses dois jornais que ocupavam posições distintas e disputavam a preferência política dos alagoanos, havia o Gutenberg que se assumiu um período neutro. Porém, segundo o próprio Craveiro Costa, o poder de Euclides Malta era tão grande que o único jornal de oposição, Jornal de Debates, foi suprimido e anulado. Alguns poucos redatores conseguiram se eleger deputado federal, como Angelo Neto, e outros debandaram para o lado de Euclides Malta.

Quando da sucessão de Joaquim Paulo Vieira de Malta por seu irmão Euclides Malta para o governo do Estado nas eleições de 1906, novamente se configurou uma oposição organizada que teve no jornal Correio de Alagoas sua arma de denúncia e combate a oligarquia maltina. Forma-se com isso, o velho partido Democrata como oposição, e seus partidários fundam o Correio de Maceió em agosto de 1906. Mas, Euclides Malta vence as eleições e governa por 3 anos, decidindo por se recandidatar na eleição seguinte. Surge então, o Jornal de Alagoas como periódico de oposição, tendo como diretor e redator o republicano radical Luiz Silveira.

Os jornais que nos interessam no momento, são os que atuaram como protagonistas pela disputa ao governo do Estado de Alagoas entre 1911 e 1940. São eles, o jornal A Tribuna, que divulgava notícias e opiniões a favor do governo de Euclides Malta, e o Jornal de Alagoas, fundado em 31 de maio de 1908 pelo jornalista pernambucano Luiz da Silveira, conhecido como $O$ espantalho das oligarquias, apelido que ganhou por ter orientado sua linha editorial para uma crítica constante da administração de Euclides Malta (RAFAEL, 2004, p. 12). O jornal A Tribuna era o órgão oficial do Partido Republicano de Alagoas e responsável pela divulgação do expediente 
do governo, ou seja, daqueles dados formais a partir dos quais é possível a recomposição de uma “memória oficial”.

\section{RACISMO E INTOLERÂNCIA RELIGIOSA NOS JORNAIS DE ALAGOAS EM} 1912

As representações sociais são sentidos produzidos coletivamente que se generalizam e se estabilizam criando uma familiaridade onde antes havia fraturas, ou falta de sentidos. As representações se entrecruzam e se cristalizam mutuamente através de uma palavra, de um gesto ou de uma reunião no cotidiano impregnando nossas relações, nossas produções e nossa comunicação (MOSCOVICI, 2003). Dessa forma, as expressões linguísticas difundidas popularmente sobre as religiões de matriz africana, se tornam o principal mote de relação para com as mesmas. E, à medida que tais expressões são corroboradas oficialmente, como no caso dos jornais impressos, a relação entre a população racista e tais Casas religiosas, que antes era de caráter privado, ganha legitimidade de ação pública racista.

A estratégia política de associar a figura do oligarca Euclides Malta às Casas de Xangô, misturando e intensificando o descontentamento com ambos, favoreceu uma explicitação hostil frente ao Xangô, ao passo que assumir a hostilidade ao oligarca era o comportamento esperado:

A repulsa provocada entre o povo em geral pelos últimos actos do $\mathrm{Sr}$. Euclides Malta rapidamente transformou-se em ódio, quando se soube que o execrado governador de Alagoas, escapando-se pelos fundos do palácio para tomar em Bebedouro, longe das vistas do povo, um expresso com destino a Cinco Pontas (...). Esse ódio que alastrara se por todos aquelles que não faziam parte da camarilha abjecta e da reduzida guarda de escribas do refinado oligarcha como enorme caldeira efervecente, augmentou, quando se teve a certeza de que o Sr. Euclides Malta, antes de sair ás escondidas, ordenára maior força na pilha da bruxaria. ${ }^{4}$

Repulsa e ódio são sentimentos que os jornais atribuem à população em relação ao

4 Jornal de Alagoas. Bruxaria: Xangô em Ação - a oligarchia e o "ogum”, o povo invade os covis - documentos preciosos - Um bode sacrificado - Exposição de ídolos e bugigangas. 4 de fevereiro de 1912. Catálogo Odè-Ayé. 
governador e, consequentemente às Casas de Xangô. Alega-se que, o governador, com sua fuga sorrateira e sua suposta e insistente relação com as casas de feitiçaria barata ${ }^{5}$, mantém um comportamento de afronta para com a população que exige, publicamente, reparações ascéticas por tantos anos de dominação pela bruxaria e pela covardia de seu governo. Tais reparações iniciaramse com a invasão dos covis de fetiche ignorante após a fuga do inepto governador para o Estado vizinho, com a intenção de livrar Alagoas definitivamente desses antros endemoniados que tanto prejuízo causou para o Estado. Citando tais prejuízos, o Jornal de Alagoas chega a enumerá-los: Tais Casas mantinham em completa desorganização a polícia, e em completa debandada todos os outros poderes orgânicos do Estado, favorecendo manhosamente uma centena de praças, que nunca existiram, em proveito dessas casas ${ }^{6}$.

Nota-se em tais matérias, que, apesar de adjetivos inferiorizantes há associados aos mesmos certo poder que parece contradizer o menosprezo frente a essas Casas. Isto é, associado aos adjetivos fetiche ignorante, antros endemoniados, feitiçaria barata vê-se a declaração de que Euclides Malta construiu uma oligarquia longa graças, justamente, ao apoio que tinha de tais Casas e que essa ligação desorganizava o Estado, a polícia e as demais esferas do poder. Além de condenar a morte pessoas que porventura se opusessem ao governo e a ligação deste estabelecida com as Casas. Como exemplo, temos o relato que consta no Jornal de Alagoas de 4 de fevereiro de 1912, em que há a denúncia de que estavam jurados de morte os candidatos da oposição Clodoaldo da Fonseca e José Fernandes de Barros Lima, e a matéria de 12 de fevereiro de 1912 que relata que no ato da devassa foram encontrados despachos malignos contendo os nomes ou figuras que representassem os opositores do governo. Isto é, o poder do xangô atua nas esferas micro condenando pessoas à morte - e macro - desestruturando o Estado.

As estratégias usadas contra o governador Euclides Malta, sendo a principal delas a sua ligação com as Casas de Xangô, não podem ser vistas como apenas um forte álibi para derrubá-lo. Precisam ser pensadas também como uma acusação conveniente que gera como consequências secundárias a sanção de um incômodo em relação à presença massiva das Casas de Xangô em Maceió. A ordem estabelecida, com suas condições de dominação, direitos e imunidades, privilégios e injustiças sustenta-se por ser sentida como natural. A dominação, assim, se mantém através de uma violência simbólica, que Bourdieu (2005, p. 7) define como uma violência suave (...) insensível, invisível as suas próprias vitimas, que se exerce essencialmente pelas vias puramente

5 Idem. Op. Cit.

6 Idem. Op. Cit. 
simbólicas da comunicação e do conhecimento, ou até do desconhecimento, do reconhecimento e do sentimento.

A ambiguidade presente na adjetivação do Xangô demonstra o quão ambígua é a relação da população com a presença negra, misteriosa e poderosa pelo oculto dos rituais e pela resistência histórica das religiões de matriz africana. Um lugar que é caracterizado como sendo foco de prostituição e indolência precisa, por ser perigoso, passar pela prova deante dos olhos bem abertos de milhares de pessoas ${ }^{7}$, a comprovar o que se designa decisão e ação exclusiva da população: adentrar os designados antros, descrita pelo Jornal de Alagoas (1912) como uma pequena sala, cheia de pinturas grosseiras, hieróglifos de ídolos, bancos imundos e porcarias misturadas a poeira e suor de negro, intitulada também de panela de feitiço. Eis todo o cortejo bestial que cercava e prestava mão forte ao governo do Sr. Euclides Malta. ${ }^{8}$

Os adjetivos pejorativos destinados a Euclides Malta eram redirecionados tanto aos xangôs, como também ao próprio Estado de Alagoas que se encontrava num pântano, numa anarquia, com a justiça postergada e vencida e os municípios entregues às figuras perigosas e ao banditismo ${ }^{9}$. Sobre o racismo linguístico propriamente dito, que é caracterizado como a discriminação arbitrária usando a cor e traços negros como forma de legitimação de argumentos inferiorizantes, há em fontes da imprensa expressões de desvalorização que caracterizaram as pessoas negras, descendentes de africanos e pertencentes ao xangô, especialmente quando se referem aos líderes religiosos: a feição de símio de Tio Salu, a risada de megera e olhos esgazeado de víbora de Tia Marcelina quando em transe, os cânticos desafinados e o infernal batuque dos rituais religiosos e a alegação de que tais pessoas são descendentes dos negros africanos - raça atrasada e fraca, ignorante e cega, que vive uma vida selvagem em cubatas que mais se assemelham a covis de feras que a Europa culta diariamente dá caça ${ }^{10}$.

As formas maniqueístas de compreender as diferenças culturais e fenotípicas a partir das categorias superior e inferior, culto e ignorante, evoluído e primitivo que são atribuídas à Europa (branca) e à África (negra) respectivamente, refletem, segundo Fanon (2008), nossa tendência

7 Jornal de Alagoas. Bruxaria: Xangô em Ação - a oligarchia e o "ogum", o povo invade os covis - documentos preciosos - Um bode sacrificado - Exposição de ídolos e bugigangas. 4 de fevereiro de 1912. Catálogo Odè-Ayé.

8 Idem. Op. Cit.

9 Idem. Op. Cit.

10 Jornal de Alagoas. Bruxaria: Xangô em confusão - Mais notas e informações - Os mystérios da carne - "Santo" de Santa Luzia do Norte. 8 de fevereiro de 1912. Catálogo Odè-Ayé. 
colonialista introjetada. Por o Brasil ser um país colonizado, explorado e miscigenado, onde foi negada a possibilidade ontológica indígena e africana, restou como única alternativa a aderência a uma concepção eurocêntrica de mundo que, ao mesmo tempo em que gera uma negação da formação brasileira, produz um engodo alienante que faz crer em um ideal de branqueamento que na prática, nunca será alcançado.

Essa crença em uma pureza racial eugênica é reconhecida nas expressões distanciadas que os jornais descrevem os eventos ocorridos contra as Casas de Xangô e seus adeptos. A forma irônica com que a notícia do Jornal de Alagoas de 8 de fevereiro de 1912 relata a exposição dos objetos apreendidos na devassa de 2 de fevereiro do mesmo ano, reflete o tom de pilheria e vitória da oposição frente às ações contra Euclides Malta e o xangô:

A sala da "Liga" estava transformada em museu e tinha o aspecto alegre de um presepe em noite de natal (...). Lá estavam garbosos, na sua fealdade de obra mal acabada, "oxalá", "oghum-taió", "oghum-china", "xangô-nilê", "xangô-china", "azuleijú", "oyá", "oxum-êkum" e tantos outros "santos" que a idolatria africana phantasia para illudir os incautos e ignorantes. ${ }^{11}$

Como se não bastasse as matérias oficiais que deturpam a imagem dos xangôs e seus adeptos, e de Euclides Malta, outras chamadas do Jornal de Alagoas, essas num tom de galhofa e cômico, se utilizam dessa suposta ligação para intensificar ainda mais a idéia pejorativa dos cultos de origem africana e desqualificar o governador Euclides Malta. Nas chamadas para o carnaval, uma sátira do que seria um cordão com oghum taió na frente, - Euclides em corpo e alma fazendo medo a carranca do entrudo ${ }^{12}$, sendo associado ao Rei do Congo, rei do mal. Ainda na mesma chamada, ridicularizam Euclides Malta chamando-o de Euclides dos telegramas, numa associação direta ao pedido que o governador fez ao governo federal no sentido de voltar à Maceió escoltado. Pedido esse que foi atendido, mas não surtiu efeito na sua manutenção no poder, pois ao voltar para Maceió depois da fuga forçada, foi recebido com protestos e o comércio fechado, fazendo voltar definitivamente para seu exílio em Recife.

O nome de Euclides Malta enegreceu, isto é, passou a ser associado com todos os adjetivos

11 Idem. Op. Cit.

12 Jornal de Alagoas. Bruxaria: Xangô em confusão - Mais notas e informações - Os mystérios da carne - "Santo" de Santa Luzia do Norte. 8 de fevereiro de 1912. Catálogo Odè-Ayé. 
que se associavam os negros e sua cultura e herança africanas. Após o dia 2 de fevereiro de 1912, com a vitória do intento da devassa e da expulsão de Euclides Malta do Estado, as descrições referentes ao seu governo se distanciam cada vez mais de críticas a administração, a organização e a política. O jornal do dia 8 de fevereiro de 1912 está repleto de referências sobre a devassa, a vitória dos opositores, como textos pejorativos, irônicos e degradantes, que estreitam ainda mais a ligação entre Euclides Malta e o xangô. A chamada de cáfila maltina, ou canalha maltina, inclui políticos partidários, apoiadores e adeptos do xangô, que são misturados na sua monstruosidade moral, hábitos corruptos, praticantes de nefandos crimes pela causa negra da Infamia. Em contrapartida, os opositores são os bons e invencíveis correligionários de honroso opposiocionismo em busca da conquista da liberdade e dessa felicidade publica que outr'ora enchia de alegria e riso o coração do povo de Alagoas. ${ }^{13}$

Também nessa mesma reportagem de 8 de fevereiro, novamente o povo surge como a instância que decidiu sobre o destino de Alagoas e que elegeu Euclides Malta como o grande homem que lhe escarrará a podridão geral, e seus correligionários como os empreiteiros da miséria de Alagoas. O povo demonstrou, não pela primeira vez, francamente o seu justo ódio ao delapidador da Honra de Alagoas.

Quer dizer, qualquer ação, mesmo que seja atroz e embalada pelo ódio, é justa quando se têm como fim a conquista do Bem soberano. É a oficialização, legitimação da barbárie, que segundo Foucault (2000), está representada pelo Direito. A guerra de raças do século XVIII vai ser retomada pelo racismo de Estado no século XIX. O direito de vida e morte associado ao soberano representa uma desnaturalização desses processos radicais, tornando-o parte do campo do poder político.

A devassa não se restringiu ao dia 2 de fevereiro de 1912, nem a pilhéria à observação dos objetos apreendidos das Casas invadidas, pois, na matéria do Jornal de Alagoas de 8 de fevereiro de 1912 registra-se que continua a caça aos covis dos feiticeiros em Pratagy, Santa Luzia do Norte, Atalaia, Tabuleiro do Pinto, Alagoas e outros lugares. E ainda registra na matéria que continuarão divulgando informações sobre essa caça, para que o público conheça essas cousas da baixa política do sr. Euclides Malta.

Enquanto Euclides Malta tentava contornar a situação à distância, não admitindo a derrota e

13 Idem. Op. Cit. 
humilhação frente à expulsão do Estado, a onda de intolerância contra o xangô se amplia e ganha a popularidade carnavalesca. Blocos carnavalescos que antes eram declaradamente de origem negra se tornam uma sátira a essa referência quando instituem desfiles que fazem críticas à religião precedidos do infernal batuque análogo, trazendo o endiabrado grupo um arsenal de "santos" $e$ “bugigangas”. Grande massa popular acompanhava o chistoso grupo; que com muito espírito exibia-se pelas ruas danças macabras. Magnífico! $!^{14}$

Satirizando e mantendo a rechaça às referências da parda tyrannia oligharquica e a negra tyrannia do xang $\hat{o}^{15}$, o povo se desinfetava dos micróbios maltinos, numa fusão entre Euclides Malta e os xangôs que simplificava em um só alvo a fonte de todos os males do Estado. O uso assim, de representações oficiais contra Euclides Malta (pardo) e o xangô (negro), são fortalecidas pelas manifestações extra-oficiais com o mesmo teor semântico: de rechaço, inferiorização, racismo, satanização e descarte. Cria-se assim, um sistema de valores, ideias e práticas com a função de estabelecer uma ordem que possibilita as pessoas a se fixarem em seu mundo e controlálo, e favorece a comunicação visto que os valores se tornam comuns, compartilhados. A concepção intolerante e racista exteriorizada no ano de 1912 se ancora numa naturalização dessas práticas a tal ponto que tornam invisíveis tanto a negritude alagoana quanto o racismo que a invisibiliza.

\section{O QUE NOS RESTA PÓS 1912: A MUTAÇÃO/MANUTENÇÃO DO RACISMO}

A manutenção da perseguição e repressão aos cultos de matriz africana em Alagoas após 2 de fevereiro de 1912 se perde de vista e se dilui nas notícias do jornal que, com o passar dos dias vai informando cada vez menos sobre esse assunto. Dessa forma, só se pode supor até onde durou a proibição dos cultos, se é que algum dia durante o século XX as Casas de Xangô se livraram da perseguição. Essa reticência surgida pelo sumiço do xangô nas páginas dos jornais é evidente quando se encontra referência sobre a religiosidade de matriz africana no Jornal de Alagoas, até onde se saiba, só no ano de 1927. Isto é, quinze anos depois do evento da devassa que se tornou pauta principal no mesmo jornal.

Quanto mais a origem das representações sociais é esquecida e sua natureza convencional é

14 Jornal de Alagoas. Prato do dia; Por nossa porta; Nas ruas; A volta do Oligarcha. 20 de fevereiro de 1912. Catálogo Odè -Ayé.

15 Jornal de Alagoas. Reflexões. 24 de fevereiro de 1912. Catálogo Odè-Ayé. 
ignorada, mais fossilizada se torna. Deixa de ser ideal para ser material ganhando uma forma definitiva através da localização da representação em determinada categoria. Assim, as representações exaustivamente expressas nos jornais de 1912 sobre o xangô, de tão "naturalizadas” se tornam também prescritivas e auto-evidentes. Isto é, as representações se impõem sobre nós através de uma estrutura anterior a nós e uma tradição que a sustenta no presente, fazendo com que não questionemos sobre elas e, consequentemente, as reproduzamos tal qual.

Dessa forma, vemos as expressões racistas e discriminatórias em relação ao xangô e aos descendentes de africanos que foram expressas no ano de 1912 serem reproduzidas em 1927, numa matéria que fala de como o brasileiro é visto pelos estrangeiros e como a Europa encara a religião de matriz africana. Tem-se nessas duas perspectivas uma contradição, já que somos considerados submundo pela herança africana, quando na Europa a feitiçaria seria valorizada:

De povo ignorante temos sido tratados, ignorante e supersticioso, herança do africano e do selvagem, pelo motivo, aliás, justo de ser o nosso povo sobremodo crente em effeitos de bruxedos mais ou menos pitorescos. ${ }^{16}$

Identificar que no ano de 1927 ainda se relacionava a África à superstição, ignorância e selvageria, e que somos vistos, enquanto brasileiros, da mesma forma pelos estrangeiros (e isso ser definido como sendo uma visão justa), significa que as representações que foram alardeadas contra a África e sua herança no Brasil no ano de 1912 persistiram através de uma propaganda vitoriosa que não precisa insistir veementemente em sua ideologia para que ela se sustente. Até porque, como consta na própria matéria, o Estado da Bahia e a cidade de Recife estão infestados dessas manifestações de baixo espiritismo, mas, Maceió, que já foi, no tempo dos Maltas, o roçado compensador desses exploradores dos pobres de espírito, passou a manifestar apenas de forma velada suas mesas de mandigueiros xangôs. Eis, assim, a evidência de que a perseguição material, humana e simbólica travada entre os anos de 1911 e 1912 surtiu efeito. Mesmo não tendo aniquilado definitivamente com as Casas de Xangô do Estado, a perseguição concentrada, ao menos manteve longe dos olhos e ouvidos dos maceioenses as manifestações do que se intitulam nos jornal de educação ainda precária.

16 Jornal de Alagoas. Bruxaria. Maceió, 18 de fevereiro de 1927. Catálogo Odè-Ayé. 
Numa matéria do Jornal de Alagoas de 4 de outubro de 1936 escrita por Edson Carneiro, há uma descrição de manifestação negro-religiosa da Bahia. Na matéria anteriormente citada, do ano de 1927, ainda se faz referência ao xangô que é tido senão como extinto, ao menos como silenciado a partir do ano de 1912. Já em 1936, essas referências alagoanas parecem perdidas, pelo menos para o novo propósito surgido na década de 1930, que é de valorização da mestiçagem, e a Bahia aparece como a fonte de observação e exemplo.

A década de 1930 é um período marcado pela ressignificação da presença negra no Brasil, de busca de uma identidade nacional. Assim, busca-se na mestiçagem valores positivos para uma afirmação brasileira, e a Bahia é considerado o Estado onde a mestiçagem enquanto referência se instaura, visto ser considerada uma das regiões com maior contingente negro do país. Jorge Amado, escritor baiano, por exemplo, traz em seus romances a utopia da democracia racial como projeto na década de 1930 (SCHWARCZ, p. 35, 2009).

As referências direcionadas à Bahia transformam a perspectiva alagoana pela nova ideologia nacional: a democracia racial justificada pelo povo mestiço. Dessa forma, importando essa ideologia, assim como importando matérias prontas de jornais da região sudeste e do Estado da Bahia, o Jornal de Alagoas traz uma nova perspectiva sobre a religião negra ou candomblés que, convenientemente, não se localiza mais no Estado de Alagoas, e sim fora dele. Revela ainda uma recente característica, pelo menos no que tange a descrição escrita até então, que inclui nos candomblés uma forte presença ameríndia nas suas manifestações. O xangô “traçado" se tornou uma espécie de eufemismo que amenizava a presença negra na religião negra. E por mais que isso pareça uma contradição infundada, a diminuição pelo menos aparente dessa referência negra, tornava a religião menos estigmatizada, já que na escala de valoração racial, o indígena é mais valorizado que o negro (MUNANGA, 2004).

O orixá Ogun passa a ser um caboclo, mistura de índio com branco, assim como Oxossi, Oxalá e Iemanjá. Xangô, apesar de ser um orixá de culto universal entre os negros da Bahia, também consente em apparecer no meio dos caboclos de Angola. ${ }^{17}$

Durante o século XIX e começo do século XX no Brasil, a mistura das raças era vista como uma degenerescência da raça branca superior. A pureza da raça branca deveria ser preservada para

17 CARNEIRO, Edison. Religiões negras da Bahia. Jornal de Alagoas. Maceió, 4 de outubro de 1936, p. 1.Catálogo Odè-Ayé. 
se preservar o mínimo de civilidade. O famoso médico maranhense radicado na Bahia do século XIX, Nina Rodrigues, citado por Schwarcz (2010), defendia que as raças humanas correspondiam a realidades distintas e, portanto, não eram passíveis de cruzamento e, se assim o fossem, geraria “descendentes degenerados”. Nina Rodrigues, Silvio Romero, Euclides da Cunha e tantos outros escritores e pesquisadores conceituados, alardeavam que a mistura das raças tendia a desfavorecer a raça tida como superior, a branca.

Após a República inicia-se um processo de busca da identidade nacional, de uma nacionalidade, que ganha ênfase na década de 1930. Buscam-se símbolos que representem essa nacionalidade, e há um apelo para elementos como a história, a tradição, ritual formalistas e a definição de um povo uno que surge graças à supressão da pluralidade (SCHWARCZ, 2010).

Assim, na década de 1930 foi difundido o ideal da mestiçagem, agora mais cultural que biológico, como maior representante do Brasil, do povo brasileiro. Graças às novas obras ufanistas de Oswald de Andrade, Mário de Andrade e seu livro Macunaíma, e finalmente Gilberto Freyre com Casa grande e senzala, é que a descrição da história do Brasil ganhou contornos de uma mestiçagem pacificada oriunda de uma escravidão complacente com as diferenças e hierarquias.

A mestiçagem ganha escopo semântico-interpretativo quando os pesquisadores e demais personagens da época que se interessam pela cultura local, passam a vê-la através do viés culturalista. O foco na mestiçagem física é convertido para a mestiçagem cultural. Tudo se mistura, não só o candomblé com a pajelança, mas o candomblé com o espiritismo de caboclo.

Vê-se assim, que apesar da nova propaganda a favor da mestiçagem e das manifestações agora mestiças da religião negra (na Bahia), ainda se sustenta ideais de inferioridade e degenerescência. Como se o que antes parecia uma ameaça a ordem social, e por isso precisava ser combatido, passa a ser visto com certa indulgência frente a mythica pobríssima dos negros bantus que, fuzionando-se com a mythica igualmente pobre do selvagem ameríndio, produziu os chamados candomblés de caboclos da Bahia ${ }^{18}$. As religiões negras, como são intituladas no jornal, passam a ser encaradas como uma amostra do folk-lore tradicional que inclui os cucumbys, o samba, a capoeira, o batuque, com a ressalva que a manifestação religiosa só veio à tona como se apresenta no final do século XIX, isto é, tardiamente.

A concepção mestiça tendeu a se generalizar, pois o discurso sobre a pureza de raças perdeu 18 Idem Op. cit. 
força, como também não havia purezas culturais e ideológicas, tudo estava necessariamente misturado a ponto de não haver cultura indígena, africana e europeia, mas apenas a cultura brasileira. Essa concepção mestiça da população e da cultura gera a concepção ideológica da democracia, onde não há barreiras biológicas nem culturais, e por isso não há desigualdade. Gera, portanto, uma confusão que se reflete na apatia das minorias que não percebem os sutis mecanismos de exclusão (MUNANGA, 2004) e na massificação de um sincretismo que beira a cegueira por não identificar peculiaridades das manifestações político-culturais, principalmente relacionados às de matriz africana. É o que se detecta na matéria do Jornal de Alagoas do ano de 1936 que denuncia o fanatismo religioso no sertão cearense, incluindo na categoria de fanatismo o Juazeiro de Padre Cícero, a Campanha de Canudos e a guerra dos quilombos. ${ }^{19}$

Porém, é indiscutível que houve uma valorização da presença dos negros no Brasil quando esta é pensada através de um sincretismo formador da nacionalidade. É o que acontece na matéria que descreve a festa de Iemanjá, sendo este orixá e seus fundamentos descritos com adjetivos positivos, como: “o maior orixá das águas”, "poderoso orixá”, “homenagem à augusta Senhora ${ }^{20}$, além de insinuar possíveis milagres como o referente a uma senhora que dança e chama a atenção na festa, sendo que dias antes não andava por causa do reumatismo que tinha. $O$ destaque à festa tão peculiar e exótica (não mais demoníaca e execrante) é que ela se desenrola no Estado da Bahia. Quando se faz referência a religião negra em Alagoas, se destaca a relação da manifestação do xangô às classes pobres, sendo uma manifestação muito modesta que procura recanto solitário ou pontos isolados na Ponta Grossa, Prado, Pharol, Levada ${ }^{21}$, etc. Além do que, o xangô no Jornal de Alagoas, aparece como notícia policial: A nossa reportagem soube que a polícia havia dado uma batida numa sessão de macumba e que a diligência obtivera o mais franco êxito. ${ }^{22}$

Na década de 1930 o xangô, agora denominado de Candomblé, volta a ser mencionado. Apesar de ainda haver menção ao barulho infernal das festas e à perseguição policial, o tratamento começa a se diferenciar quando abrem espaço para um adepto da religião falar ao jornal e afirmar que o candomblé é uma religião como outra qualquer ${ }^{23}$ e quando associam cada orixá a um santo

19 Jornal de Alagoas. Fanatismo, consequência moral da superstição e penúria. Maceió, 27 de setembro de 1936, p. 3. Catálogo Odè-Ayé.

20 Jornal de Alagoas. A festa da Rainha do Mar. Maceió, 30 de setembro de 1936, p. 3. Catálogo Odè-Ayé.

21 Jornal de Alagoas. No silêncio da noite o candomblé de “Oxum” trabalhava. Maceió, 11 de outubro de 1936, p. 8. Catálogo Odè-Ayé.

22 Jornal de Alagoas. No silêncio da noite o candomblé de "Oxum" trabalhava. Maceió, 11 de outubro de 1936, p. 8. Catálogo Odè-Ayé.

23 Idem. Op cit. 
católico correspondente. Isso demonstra que o silenciamento perpetrado em 1912 não foi completo, já que o "barulho infernal" insiste em se manter, mas, há uma espécie de tratamento diferencial no jornal comparativamente aos constatados nos anos anteriores. Apesar da prisão dos adeptos e a apreensão dos objetos litúrgicos se repetirem, os adeptos já possuem nomes e direito a declararemse no jornal. Isto é, houve uma humanização do xangô graças à mestiçagem ou ao sincretismo que branqueia a religião, tornando-a mais aceitável.

Não se muda a concepção racista, hierárquica sobre a população negra que continua atrasadíssima e com dificuldade em generalizar, pois, não conseguem diferenciar a si da natureza. Mas, há uma complacência paternalista com essas criaturas tão fantasiosas e infantis, que ouvem barulho no mato, e imaginam que uma árvore (Iroco) sangra como gente. Assim, o negro oscila em sua função de ameaça a ordem social e cultural estabelecida e sua função de animar a paisagem do Brasil com sua imaginação. ${ }^{24}$

Há, portanto, uma ambivalência presente nas notícias da década de 1930. Se por um lado, Alagoas é herdeira de uma tradição racista e discriminatória culminada no ano de 1912 com atos de violência generalizados contra as manifestações negras e os próprios negros, por outro lado, precisa se adequar às modernas concepções de brasilidade que incluem os negros como fator inevitável dessas concepções. Já que, durante as décadas após a abolição, a presença negra no Brasil não pode ser suprimida, ela passou a ser assumida, porém, com determinadas condições que dizem respeito a sua gradativa diluição na mestiçagem e sua subalternização como mão de obra a ser explorada.

A inclusão de matérias que ressaltam as vantagens da mestiçagem e que vêm com benevolência os cultos negros na Bahia demonstram a necessidade de familiarizar-se com as mudanças acontecidas no resto do país em relação à presença negra. Ao mesmo tempo em que ainda denuncia certa dificuldade em compreender com a mesma benevolência a presença negra em Alagoas. Por isso, mesclam-se na década de 1930 tanto matérias que exaltam os orixás baianos, quanto as que condenam os batuques infernais dos xangôs em Maceió. Segundo Moscovici (2003), a dinâmica das relações é uma dinâmica de familiarização, onde as pessoas, objetos e símbolos são percebidos e compreendidos em relação a prévios encontros e paradigmas. Com isso, a memória prevalece sobre a dedução, o passado sobre o presente. Então, para que uma concepção arraigada seja transformada, há que haver uma repetição do novo que a esgote e substitua.

24 CARNEIRO, Edson. Culto da natureza entre os negros bantús. Jornal de Alagoas. Maceió, 4 de novembro de 1936, p.4. Catálogo Odè-Ayé. 
Assim, as variações nas notícias do Jornal de Alagoas demonstram essa passagem entre uma concepção familiar racista, e uma nova concepção mestiça ainda estranha. A última notícia de 1936 denuncia uma batida policial a uma Casa de Xangô com "infernal batuque", mas que já possibilita uma concepção mais humana de seus adeptos quando os dá voz, nome e cargos. Em 1937, a única matéria que se refere à questão negra é a divulgação do Primeiro Congresso Afro-brasileiro que homenageia Nina Rodrigues e é presidido pelo alagoano Arthur Ramos ${ }^{25}$. Esse congresso repercute ainda no ano de 1938, quando uma extensa matéria de 15 de maio revisa a história do negro no Brasil, desde sua chegada em tumbeiros com péssimas condições, até sua sobrevivência em condições desumanas e de sadismo de seus senhores.

A figura do negro se torna simpática frente a sua purgação na história da escravidão, com seus castigos e flagelos, dando à descrição histórica certa affectação de lyrismo ao olhar para o africano $^{26}$. Nessa mesma matéria se admite o risco de endeusar o africano após o Congresso afrobrasileiro, coisa que, sobremaneira não se deseja, mas precisa-se admitir que o negro não é esse monte de lixo, nem é a pureza que querem nos fazer crer para nos redimir dos maus tratos sofridos por eles. Porém, frente a tudo que sofreu, sobrevivendo e nos agraciando com sua presença e nossa cordialidade mútua, o brasileiro foi amaciado graças a essa mistura de raças. O negro tem vocação para santo $^{27}$.

Mesmo com uma nova e já recorrente concepção supostamente positiva da presença do negro no Brasil e em Alagoas, ainda há a insistência do que foi e continua sendo a concepção familiar sobre essa camada da população, e mais precisamente sobre um tema considerado tabu: a religião. Assim, por mais que as expressões declaradamente racistas tenham, aos poucos, sido abandonadas e a presença dos africanos e seus descendentes no Brasil tenha começado a ser valorizada, a perseguição afro-religiosa não seguiu o mesmo percurso. Nas matérias que ainda insistem em tratar das religiões afro-brasileiras em Alagoas, estas vêm associadas sempre a ilegalidade: Mandou prender 'Pedro Caminhão' por pratica de macumba, contrariando deste modo as determinações da Delegacia da Ordem Policial Social. ${ }^{28}$

As notícias de jornais dos anos de 1930 vacilam entre a concepção tradicional de uma

25 Jornal de Alagoas. Homenagem a Nina Rodrigues. Maceió, 30 de maio de 1937, s/p. Catálogo Odè-Ayé.

26 Jornal de Alagoas. O negro em Alagoas: Na integra a palestra do escritor Valdemar Cavalcanti. Maceió, 15 de maio de 1938, p. 3. Catálogo Odè-Ayé.

27 Idem Op. Cit.

28 Jornal de Alagoas. Macumba para ella deixar. Maceió, 5 de março de 1938, p. 8. Catálogo Odè-Ayé. 
natural marginalidade da cultura e do povo negro, e uma nova exaltação da história e presença negra no Brasil presente em denúncias de maus tratos ${ }^{29}$, fruto da concepção mestiça da identidade brasileira, e apontamentos críticos sobre a literatura nacional que, a exemplo do livro de Alberto Insúa ("Preto de Alma Branca") do ano de 1926, ou invisibilizam o negro em suas histórias, ou os descreve como inferiores, humilhados e infelizes:

Tão grande é a incomprehensão do novellista que intitula o livro de "o preto que tinha a alma branca", dando desse modo um sentido de baixesa á cor negra, symbolismo illógico e anti-scientífico no caso. ${ }^{30}$

O problema parece não ser mais a presença negra em terras alagoanas, e sim a afronta da insistência cultural, ou mais precisamente, religiosa. A presença da macumba, o xangô e outras denominações novas associadas à religião negra, continua sendo preterida. Até aí nenhuma novidade, a perseguição continua. Mas, a descrição dos ritos tem se configurado e ganhado nuances de outras misturas. Se até então o xangô se associou ou começou a ser associado com a pajelança, em 1939 ganhou contornos Kardecistas, seja na denominação do pai de santo ou babalorixá que passa a se chamar médium, seja na própria ritualística que agora se denomina sessão, acontecida numa sala ampla, tendo dispostos os apetrechos necessários ao rytho branco ${ }^{31}$.

Independente das novas formas sincréticas que a religião negra vinha sofrendo pós 1912, e seja por quais motivos, se por estratégia de sobrevivência ou se por forças das contingências sóciohistóricas, sua manifestação continuava sendo perseguida e vista como ilegal. Numa mesma reportagem os intitulados ora macumbeiros, ora médiuns, continuavam sendo presos e proibidas as sessões ou macumbas.

Ainda são "bárbaras” as manifestações, ainda são apreendidos objetos rituais e descritos com asco, definidos como "bruxaria”. Há uma relativização da presença negra em Alagoas, iniciada

29 Jornal de Alagoas. Escravos, ainda, no interior da Parahyba. Maceió, 19 de fevereiro de 1939, p. 4. Catálogo OdèAyé.

30 BASTOS, Humberto. O negro na literatura brasileira. Jornal de Alagoas. Maceió, 9 de abril de 1939 , p. 5. Catálogo Odè-Ayé.

31 Jornal de Alagoas. Na Macumba: quando gritam: "A polícia!" houve um terror pânico o "médium" emudeceu como por encanto e as mulheres escapuliram pelos quintaes quebrando as cercas. Maceió, 23 de julho de 1939, p. 12. 
a partir da inclusão de matérias baianas ou sobre a Bahia e, finalmente, a inclusão de uma matéria sobre Alagoas. Porém, os lugares comuns estabelecidos durante os séculos da escravidão e décadas após a abolição tendem a se cristalizar e gerar, dentro da banalidade das ideias naturalizadas, uma cultura e um mistério que faz esses lugares comuns ao mesmo tempo compulsivos e fascinantes (MOSCOVICI, 2001). Isto quer dizer que, por mais que novas ideias e valores sejam forjados sobre a cultura negra, antigos não são descartados. O que é possível acontecer é uma sobreposição de ideologias que hora mascara o racismo, hora o declara, num jogo estratégico de interesses políticos.

\section{CONSIDERAÇÕES FINAIS:}

O episódio do “Quebra de Xangô” de 1912 em Alagoas dá margem para inúmeras compreensões sobre o preconceito religioso em Alagoas. Afinal, um fato histórico de tamanha violência e de extensa perduração no tempo e espaço (pois não se reduziu a perseguições na capital do Estado) provoca marcas definitivas no presente.

Porém, por mais marcante e extenso que tenha sido tal evento, ele tem se apresentado com um misto de confusão e surpresa por boa parte da população alagoana: O "Quebra Xangô” era e ainda é desconhecido no século XXI. Alguns pesquisadores, artistas, cineastas e afro-religiosos, têm trazido à tona a discussão sobre esse evento. E, assim como o evento vem sendo estudado recentemente, muitas hipóteses sobre o mesmo ainda estão para serem formuladas. Dentre essas hipóteses, a mais divulgada versa sobre o possível silenciamento, senão, extinção dos cultos tradicionais de religião negra em Alagoas. Silenciamento no sentido de transmutação do que seria o xangô até o ano de 1912, e no que se transformou após essa data: uma espécie de culto discreto e silencioso com intuito de despistar a perseguição policial e o racismo. O que se denomina “silenciamento do xangô” também acometeu os estudiosos da temática negra em Alagoas nos anos subsequentes a devassa de 1912.

Graças ao silenciamento das elites (RAFAEL, 2004; DO BEM, 2008; CAVALCANTI \& ROGERIO, 2008) os documentos históricos e livros que chegaram aos dias de hoje, trazem referências muito pontuais acerca do que caracterizava a presença negra em Alagoas. Arthur Ramos, alagoano e um dos mais afamados antropólogos da década de 1930 e 1940, se restringe a reinterpretar a obra de Nina Rodrigues, que traz como mote a valorização da África, o que o torna, de certa forma, indiferente às manifestações negras alagoanas (RAFAEL, 2012, p. 11). Abelardo 
Duarte (2010), também alagoano, traz em seu livro sobre o "Folclore Negro das Alagoas" uma visão já explícita no título do seu livro: através da folclorização. ${ }^{32}$

Assim, compreender Alagoas pela premissa de seu passado é um trabalho árduo, visto que o acesso a processos judiciais ou inquéritos policiais que remontam ao início do século XX é impossível, já que foram destruídos ou estão inacessíveis, assim como os documentos sobre a escravidão que, em sua maioria, foram queimados a mando de Rui Barbosa (BARBOSA, 1988).

Dessa feita, nos resta o acesso aos jornais de grande circulação à época, quais sejam: A Tribuna - órgão oficial do Partido Republicano em Alagoas, responsável pelo expediente do governo; e, principalmente, o Jornal de Alagoas surgido em 1908 como manifesto de oposição ao governo de Euclides Malta e, por isso, o principal divulgador da ofensiva contra o dito governador e às Casas de Xangô.

Dentro de nossa perspectiva, aproveitamos os anos de 1911 e 1912, período em que o xangô desponta como um dos principais assuntos nos Jornais graças a sua associação ao então governador Euclides Malta, para apreender sobre o racismo impresso em expressões inferiorizantes de deslegitimação e violência contra os adeptos da religião de matriz africana e suas referências. Tais expressões se configuram como representações sociais, que são palavras, expressões e ideias familiares a maioria da população graças a um processo de pensamento baseado na memória e em conclusões passadas (MOSCOVICI, 2003). Isto é, as representações divulgadas sobre o xangô nos jornais, nada mais são dos que ideias recorrentes e familiares à população por motivo da escravidão e de todo o passado colonial, de imposição de uma ideologia que hierarquiza a cor e a raça. Assim, o que o Jornal de Alagoas favorece é uma espécie de oficialização do pensamento recorrente, com o intuito de deturpar a imagem do governador Euclides Malta e destituí-lo do cargo, mas, também e principalmente, declarar guerra a uma herança que insiste em resistir e manifestar seu poderio: a herança negra.

Constatamos, pois, que termos como: Bruxaria, feitiçaria barata em referência aos cultos de xangô, covis de feitiço ignorante, antros endemoniados, foco de prostituição e indolência em referência ao espaço dos cultos, além das expressões de degradação moral e estética relacionadas aos negros e as negras frequentadores dos cultos, como prostituição e indolência, símio, megera

32 A visão folclorizante enxerga a herança negra como sobrevivência, como restos de um passado a se preservar, fossilizado no museu, nunca como um conjunto de forças em processo. (LOPES, Nei. 1994 apud BARBOSA, W. N., 1994, p. 9) 
refletem toda uma gama de representações sociais oriundas do período escravista brasileiro, em que a escravidão negra para ser justificada usava do álibi da inferiorização dos africanos. Mas, não só das heranças escravistas de hierarquia racial se sustentam as representações encontradas nos jornais de Alagoas do começo do século XX, também do período pós-abolicionista que instaurou o racismo científico como forma de justificar a nova condição do ex-escravizado. O ex-escravizado passou a ser visto como alguém que não tinha vocação para o emprego assalariado por conta de sua indolência, tendência à criminalidade, dentre outras, tudo isso para justificar a política imigrantista com intenção de branqueamento da população (AZEVEDO, 2008).

Tais expressões encontradas na campanha anti-maltina de 1911/1912 são reproduzidas no final da década de 1920 quando se define o brasileiro como sendo ignorante e supersticioso por causa de sua herança africana selvagem. Além das expressões que se repetem como bruxaria, inclui-se novas expressões como baixo espiritismo e mesas de mandingueiros xangôs, que demonstram uma transmutação do culto do xangô através de uma aproximação ao espiritismo kardecista ou à pajelança, ou ainda, uma confusão de interpretação recente sobre os xangôs, visto haver esses novos elementos de religiosidade em Maceió.

Já durante toda a década de 1930, houve uma mudança qualitativa em relação ao tratamento dispensado à temática negra no Jornal de Alagoas. O Brasil inteiro se devotava à busca de uma identidade nacional unificada, e a favor dessa busca estavam literatos, pesquisadores, políticos e estudiosos, dentre eles, Gilberto Freyre que em seu livro “Casa Grande e Senzala” mostrou aos brasileiros o ponto de vista de que a escravidão, apesar de seu caráter relativamente violento, possibilitou a junção das raças branca, indígena e negra, formando uma única população mestiça. A mestiçagem se tornou então, um fator de valorização nacional, e a partir daí se elegeu alguns dos seus aspectos para serem ovacionados. Nesse caso, a herança da etnia nagô na Bahia foi o principal foco de estudos e visibilização não só de baianos e residentes no Estado da Bahia, mas também dos alagoanos que negligenciaram os estudos sobre a herança negro-banto local, pela eleição da etnia nagô como a mais “evoluída” na escala gradativa em que encaixaram a África (LOPES, 1988).

Quando, por ventura, se referiam às casas afro-religiosas em Alagoas, estas eram notícias nas páginas policiais ainda como denúncia de ilegitimidade, o que esclarece dois pontos importantes sobre as consequências do "Quebra de Xangô": o primeiro se refere à manutenção incessante da proibição e perseguição ao xangô no Estado mesmo no período em que há uma ressignificação da presença negra no país; o segundo demonstra que, ao contrário do que alguns pesquisadores 
defendem $^{33}$, não houve o chamado silenciamento do xangô após 1912, visto que este continuava incomodando a população com seu barulho infernal na década de 1930.

Entre os anos de 1905 e 1940 houve ápices de divulgação de um racismo e intolerância religiosa nos jornais e panfletos diversos, relacionados a interesses políticos e a manifestação de um colonialismo insistente que demonstra um menosprezo à cultura negra, ao mesmo tempo em que um receio supersticioso de seu poder. Os ápices foram nos anos de 1911 e 1912, posteriormente houve destaque na década de 1930 quando uma onda em nível nacional de estudos sobre a população negra contaminou Alagoas, que passou a divulgar em seus jornais artigos sobre esses estudos. Enquanto, de um lado, em destaque no Jornal de Alagoas, se descrevia o folclore, a história e a religião negro-baiana, com menos destaque se avizinhava denúncias de uma presença negra incômoda que insistia em sobreviver mesmo com tanta perseguição: $\mathrm{O}$ xangô. $\mathrm{O}$ xangô, que passa a ser chamado de "macumba” e outras denominações correntes à época, ainda é visto como uma manifestação inferior da herança africana e, por isso, não merece os estudos e os destaques dados às manifestações principalmente afro-baianas.

Também é na década de 1930 que surgem descrições do xangô e os chamados Candomblés tendo associado a eles a presença indígena mais demarcada, além do próprio espiritismo kardecista com a ampliação da Umbanda (ORTIZ, 1999). Assim, tanto as Casas de Xangô foram se transmutando por motivo do processo histórico local, e influências nacionais, como a forma com que passaram a ser vistas perpassa por essa transmutação adaptativa, onde há uma forma mais amena de se descrever o xangô quando este é visto pela ótica sincrética, com índios e santos.

De qualquer forma, com a valorização da mestiçagem, a descriminalização das religiões de matriz africana no governo de Getúlio Vargas e a corrente valorativa da herança negra, as expressões usadas para descrever e pontuar a presença negra e do xangô em Alagoas passaram de ataques diretos, insultos e certo temor pelo suposto poder que detinham (relacionado ao mal) para uma forma mais branda, mas não menos pejorativa, que se não deturpa a imagem da africanidade em Alagoas (nos corpos e culturas), a desdenha encaixando-a num incômodo ainda por se resolver, e numa folclorização forçada que a destitui de poder mobilizador.

33 Como Gonçalves Fernandes (1941), Ulisses Rafael (2004), etc. 


\section{REFERÊNCIAS BIBLIOGRÁFICAS:}

\section{Fontes:}

A TRIBUNA (Maceió) - 1905 - 1911.

JORNAL DE ALAGOAS (Maceió) - 1905 - 1940.

\section{Livros:}

APRATTO, Douglas. Metamorfose das Oligarquias. Maceió: EdUFAL, 2009.

AZEVEDO, Célia Maria M. Onda negra, medo branco - O negro no imaginário das elites do século XIX. $3^{\text {a }}$ Ed. São Paulo: Annablume, 2008.

BAKHTIN, M. Marxismo e Filosofia da Linguagem. 14a Ed. São Paulo: Hucitec, 2010.

BARBOSA, Wilson N. Atrás do muro da noite; dinâmica das culturas afro-brasileiras. Brasília: Ministério da Cultura. Fundação Cultural Palmares, 1994.

BOURDIEU, Pierre. A Dominação Masculina. $4^{\mathrm{a}}$ Ed. Rio de Janeiro: Bertrand, 2005. . A Economia das Trocas Simbólicas. São Paulo: Perspectiva, 2007.

CAVALCANTI, Bruno César \& ROGÉRIO, Janecléia Pereira. Mapeando o Xangô - notas sobre mobilidade espacial e dinâmica simbólica nos terreiros afro-brasileiros em Maceió. In: Revista Kulé Kulé: Religiões Afro-brasileiras. Maceió: EdUFAL, 2008.

CERTEAU, M. de. A Invenção do Cotidiano - Artes de fazer. $3^{\text {a }}$ Ed. Petrópolis: Editora Vozes, 1998.

CHAUÍ, M. O que é ideologia. São Paulo: Brasiliense, 2001.

CONRAD, Robert. Os Últimos Anos da Escravatura no Brasil. Senado Federal, Conselho Editorial: Brasília, 2002.

COSTA, Craveiro. Cem anos de Jornalismos - Memória histórica sobre o jornalismo em Alagôas. Revista do Instituto Archeologico e Geographico Alagoano. Pp. 78-130. Maceió, 1931.

DO BEM, Arim Soares. Dominação da Subjetividade e repressão à religiosidade africana: uma práxis transatlântica secular. In: Revista Kulé Kulé: Religiões Afro-brasileiras. Maceió: EdUFAL, 2008.

DUARTE, Abelardo. Folclore Negro das Alagoas - Áreas da cana-de-açúcar. Pesquisa e interpretação. $2^{\mathrm{a}}$ Ed. Maceió: EdUFAL, 2010.

FOUCAULT, M. Em defesa da sociedade. São Paulo: Martins Fontes, 2000.

FANON, F. Peles negras, máscaras brancas. Salvador: EdUFBA, 2008. 
FERNANDES, Gonçalves. O sincretismo religioso no Brasil - seitas, cultos, cerimônias e práticas mágico-curativas entre as populações brasileiras. Curitiba, São Paulo, Rio de Janeiro: Guaíra Ltda, 1941.

FREYRE, Gilberto. Casa Grande e Senzala. 43 ed. Rio de Janeiro: Record, 2001.

IANNI, O. Escravidão e Racismo. São Paulo: Editora Hucitec, 1978.

JÚNIOR, Félix Lima. Maceió de Outrora. Vol. 2. Maceió: EdUFAL, 2001.

JÚNIOR, Manuel Diégues. O Bangüê nas Alagoas - Traços da influência do sistema econômico do engenho de açúcar na vida e na cultura regional. 3ª Ed. Maceió: EdUFAL, 2006.

LINDOSO, Dirceu. A Razão Quilombola - Estudo em torno do conceito quilombola de nação etnográfica. Maceió: EdUFAL, 2011.

. A Utopia Arma - Rebeliões de pobres nas matas do Tombo Real. $2^{\mathrm{a}}$ edição revisada. Maceió: EdUFAL, 2005.

LOPES, Nei. Bantos, Malês e Identidade Negra. Rio de Janeiro: Forense Universitária, 1988.

MACIEL, Osvaldo B. A. Filhos do Trabalho, Apóstolos do Socialismo: Os tipógrafos e a construção de uma identidade de classe em Maceió (1895-1905). 2004.156 p. (Dissertação de mestrado em História) - Programa de Pós-graduação em História, Centro de Filosofia e Ciências Humanas, Universidade Federal de Pernambuco, Recife, 2004.

MOSCOVICI, S. Representações Sociais - Investigações em Psicologia Social. $4^{\mathrm{a}}$ Ed. Petrópolis: Editora Vozes, 2003.

MOURA, Clóvis (org.). Os Quilombos na Dinâmica Social do Brasil. Maceió: EdUFAL, 2001.

MUNANGA, K. Rediscutindo a mestiçagem no Brasil. Identidade nacional versus identidade negra. Belo Horizonte: Autêntica, 2004.

ORTIZ, R. A morte branca do feiticeiro negro: Umbanda e sociedade brasileira. São Paulo: Brasiliense, 1999.

RAFAEL, Ulisses Neves. Xangô Rezado Baixo: Um estudo da perseguição aos terreiros de Alagoas em 1912. 2004. 262 p. (Tese de doutorado em Antropologia) - Programa de Pósgraduação em Sociologia e Antropologia, Instituto de Filosofia e Ciências Sociais, Universidade Federal do Rio de Janeiro, Rio de Janeiro, 2004.

VIEIRA, Elaine. O Trabalho: breve visão da concepção de castigo da antiguidade cristã, valor social afirmado na Enciclopédia Rerum Novarum no século XIX e despontar no século XXI como valor bioético. Revista Bioéthikus. Centro Universitário São Camilo, 2010.

Artigos:

LACOMBE, Américo J; SILVA, Eduardo; BARBOSA, Francisco de A. Rui Barbosa e a Queima dos arquivos. Brasília: Ministério da Justiça; Rio de Janeiro: Fundação Casa de Rui Barbosa, 1988, p. 11-26. 
Acesso em: $\quad$ http://www.casaruibarbosa.gov.br/dados/DOC/artigos/aj/FCRB_FranciscodeAssisBarbosa_Apresentacao_livro_RuiBarbosa_queima_arquivos.pdf

SCHWARCZ, Lilia Moritz. Gilberto Freyre: adaptação, mestiçagem, trópicos e privacidade em Novo Mundo nos trópicos. Mal-estar na cultura. Rio Grande do Sul: UFRGS, Abrilnovembro 2010.

. O artista da mestiçagem. São Paulo: Companhia das Letras, 2009.

RAFAEL, Ulisses Neves. Os silêncios do Quebra. Maceió: 2012. Revista Graciliano, Maceió, v. $\mathrm{V}, \mathrm{n}^{\circ} 13$, p. 6-16, março/abril 2012. 